American Journal of Environmental Sciences 5 (3): 273-277, 2009

ISSN 1553-345X

(C) 2009 Science Publications

\title{
The Development of Ni/Dolomite Catalyst in Simultaneous Biomass Gasification and Reforming in Fluidized Bed
}

\author{
${ }^{1}$ Anawat Ketcong, ${ }^{1}$ Tharapong Vitidsant and ${ }^{2}$ Kaoru Fujimoto \\ ${ }^{1}$ Department of Chemical Technology, Faculty of Science, Chulalongkorn University, Phayathai Rd., \\ Pathumwan, Bangkok 10330, Thailand \\ ${ }^{2}$ Department of Chemical Processes and Environmentals, Faculty of Environmental Engineering, \\ The University of Kitakyushu, 1-1, Hibikino, Wakamatsu-Ku, Kitakyushu, \\ Fukuoka 808-0135, Japan
}

\begin{abstract}
Simultaneous gasification and steam reforming of the biomass on Ni/dolomite catalyst in fluidized bed reactor were studied in the gaseous production in the one stage reactor. Problem statement: The parameters such as temperature, steam flow rate, biomass feed rate, gas flow rate for fluidization, oxygen flow rate and catalyst types were studied to produce the high gaseous products including tar elimination. Approach: The temperature at $780^{\circ} \mathrm{C}$, steam flow rate of $222 \mathrm{mmoL} \mathrm{h}^{-1}$, gas flow rate for fluidization $450 \mathrm{~mL} \mathrm{~min}{ }^{-1}$ and oxygen input $50 \mathrm{~mL} \mathrm{~min}{ }^{-1}$ were found to be the suitable conditions. The Ni/Dolomite and the developed Ni/Dolomite were studied about their performance. Results: It was confirmed that $\mathrm{Ni} /$ Dolomite and newly developed $\mathrm{Ni}-\mathrm{WO}_{3} /$ Dolomite show high performance in biomass gasification. Conclusion/Recommendations: It was claimed that $\mathrm{Ni} /$ Dolomite catalyst was the effective and give best performance for tar cracking. Newly developed $\mathrm{Ni}-\mathrm{WO}_{3} /$ Dolomite catalyst was investigated to resist sulfur nd coking. Three types of catalyst were used in the biomass gasification, which are Ni/Dolomite, Ni/Dolomite+Silica binder and $\mathrm{Ni}$ $\mathrm{WO}_{3} /$ Dolomite. From the XRD analysis, structures of type 1 (Ni/dolomite) and type 2 (Ni/Dolomite+Silica binder) were similar which were in $\mathrm{CaCO}_{3}, \mathrm{MgNiO}_{2}, \mathrm{NiO}$ and $\mathrm{MgO}$ forms. Type 3 (Ni- $\mathrm{WO}_{3} /$ Dolomite) was $\mathrm{CaWO}_{4}, \mathrm{MgNiO}_{2}, \mathrm{NiO}$ and $\mathrm{MgO}$ forms. When the catalytic gasification was operated, newly Ni- $\mathrm{WO}_{3} /$ Dolomite catalyst was the best catalyst for bamboo and palm shell biomasses, which could produce the high carbon monoxide and hydrogen but low methane and carbon dioxide were found. Carbon deposition on catalyst was around $0.37 \mathrm{mg}$ according to the TG analysis.
\end{abstract}

Key words: Biomass gasification, fluidized bed reactor, Ni/dolomite catalyst, tar reforming

\section{INTRODUCTION}

Biomass is the production of photosynthesis and is thought to be one of the most promising renewable energy resources. Gasification of biomass with steam has been known to produce gases $\left(\mathrm{H}_{2}, \mathrm{CO}, \mathrm{CO}_{2}\right.$ and $\mathrm{CH}_{4}$ ), light and heavy hydrocarbon (tar) and char.

The biomass gasification is the primary process for producing the synthesis gas lead to the production of DME, methanol or LPG in the secondary process. Absolutely, tar and char still be the major problems in the catalytic gasification. The biomass gasification apparatus was continuously developed to the high performance in the gas production ${ }^{[1-11]}$.

Recently, Ni-supported dolomite (Ni/Dolomite) catalyst ${ }^{[12-14]}$ was studied for catalytic performance in the tar gasification to claim that it is an effective catalyst for fixed bed gasification of tar. The $\mathrm{Ni} /$ Dolomite catalyst showed excellent activity for the gasification of tar and its model compounds (toluene and naphthalene) and resistance against coking.

In the present study, the new apparatus, 1-stage system of biomass gasification with fluidized bed reactor, was modified and set up with the stainless steel reactor. The main objective of this research was to find the conditions that can completely eliminated the wastes (tar and char) from the reaction lead to the useful gases. We expect that this results can lead to the further research on the biomass gasification with in-situ tar and char gasification process in a catalytic fluidized bed as the first process and then through the methanol or DME process as the second process.

Corresponding Author: Tharapong Vitidsant, Department of Chemical Technology, Faculty of Science, Chulalongkorn University, Phayathai Rd., Pathumwan, Bangkok 10330, Thailand Tel: +66-2-2187517 Fax: +66-2-2555831 
Moreover, the effects of temperature, steam rate, fluidized velocities, biomass feeding rate, oxygen input including catalysts which are the main role for biomass gasification with fluidized bed reactor by continuous biomass feeding rate were investigated the tendency of products that occurred. The result of them and the efficiency of new apparatus were described in this study. The differences of catalyst such as $\mathrm{Ni} /$ Dolomite, $\mathrm{Ni} /$ Dolomite $+\mathrm{SiO}_{2}$ binder and the newly developed $\mathrm{Ni}_{-} \mathrm{WO}_{3} /$ Dolomite (Takuma Co. Ltd in Japan) were investigated the characteristic in the gasification process for eliminating tar.

\section{MATERIALS AND METHODS}

Figure1 shows the schematic diagram of biomasses gasification with fluidized bed. The cylindrical stainless steel tube reactor with inner diameter of $38.7 \mathrm{~mm}$ and $705 \mathrm{~mm}$ of height was located inside an electric furnace, which is heated by temperature programmed method. The flow of Argon and hydrogen with gasifying medium (steam) from water pump were fed into evaporator and then flowed through a gas distributor which is placed at the bottom of the reactor and contain $\mathrm{Ni}$ /Dolomite catalyst. Before gasification occurred, $\mathrm{Ni} /$ Dolomite had to reduce in hydrogen at $700^{\circ} \mathrm{C}$ for $2 \mathrm{~h}$ in order to be the effective and performance catalyst. The various amounts of biomasses were fed from the top under gravity by continuous feed and analyzed every $4 \mathrm{~min}$. The gaseous products flow through the top of reactor into impinger bottles which contained isopropyl alcohol (IPA) for tar trap and were analyzed by TCD gas chromatograph. The effects of temperature at $780^{\circ} \mathrm{C}$ and steam flow rate at $222 \mathrm{mmoL} \mathrm{h}^{-1}$ were selected as the suitable condition to investigate the performance of $\mathrm{Ni} /$ Dolomite catalyst.

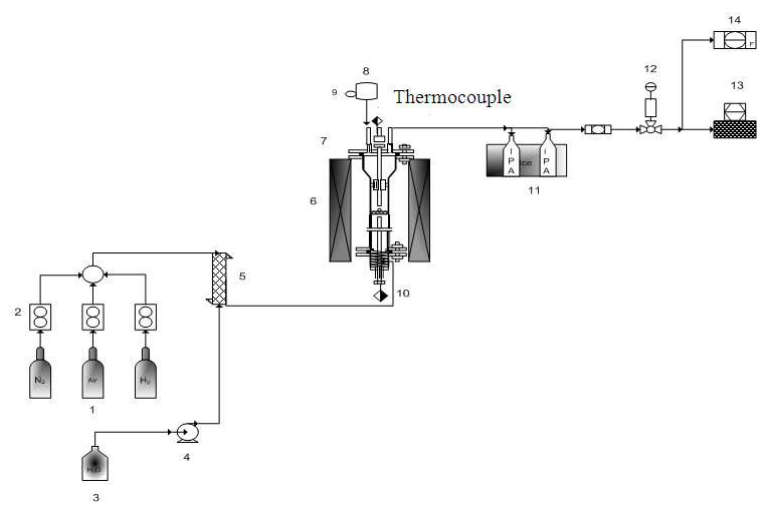

Fig. 1: Schematic diagram of the experimental set up for biomass fluidized bed gasification

\section{RESULTS}

Figure 2 showed the result of three types of catalyst on gas compositions in gasification with fluidized bed. Bamboo was used to check the products because they are so interesting and abundant in our country. According to the Fig. 2, the biomass feed rates at $30 \mathrm{~g} \mathrm{~h}^{-1}$ were fed continuously at temperature $780^{\circ} \mathrm{C}$, steam flow rate $222 \mathrm{mmol} \mathrm{h}^{-1}$, gas flow rate for fluidization $450 \mathrm{~mL} \min ^{-1}$ and $\mathrm{Ni} /$ Dolomite catalyst 10 g. Compare with three types of $\mathrm{Ni} /$ Dolomite catalysts, it may be seen that the newly $\mathrm{Ni}-\mathrm{WO}_{3} / \mathrm{MgO}-$ $\mathrm{CaO}$ catalyst can produce the synthesis gas higher than $\mathrm{Ni} /$ Dolomite and $\mathrm{Ni} /$ Dolomite $+\mathrm{SiO}_{2}$ binder. Also, carbon dioxide and methane were decreased. Hence, this experiment can be suggested the result of Srinakruang et $a l^{[12-13]}$, which used toluene and naphthalene as tar model, that the performance of $\mathrm{Ni}$ /Dolomite can be operated in the real biomass gasification for tar elimination to form the synthesis gas. Compare with the literature of Asadullah et al. ${ }^{[2-9]}$ who studied the cedar wood gasification on $\mathrm{Rh} / \mathrm{CeO}_{2} / \mathrm{SiO}_{2}$ catalyst, the advantage of $\mathrm{Rh} / \mathrm{CeO}_{2} / \mathrm{SiO}_{2}$ catalyst could play at the low temperature and also could produce the high carbon conversion but the cost of this catalyst is relatively higher than conventional catalyst, since the work was done at the laboratory level. The chemicals used for catalyst preparation were high grades and expensive. Thus, Ni/Dolomite catalyst was also another choice in biomass gasification due to the properties of cost, preparation and life time were completely the appropriate catalyst ${ }^{[12-14]}$, which can be brought in a commercial scale laboratory.

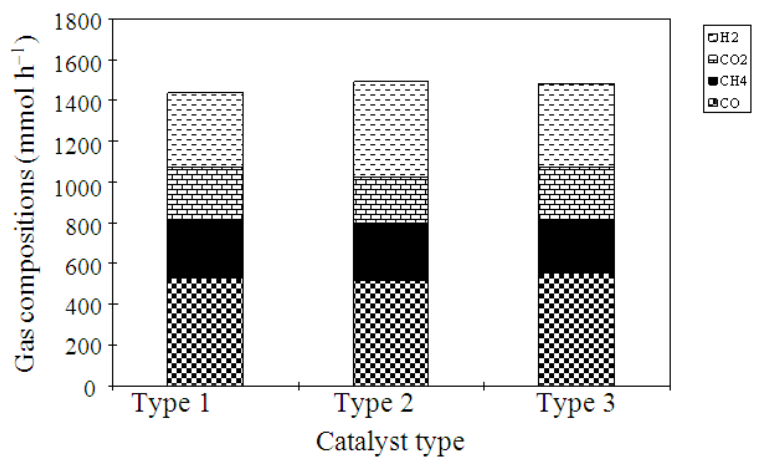

Fig. 2: The effect of Ni/Dolomite catalyst on the gas compositions in biomass gasification and reforming with fluidized bed, Type 1: Ni/Dolomite; Type 2: Ni/Dolomite $+\mathrm{SiO}_{2}$ binder; Type 3: $\mathrm{Ni}-\mathrm{WO}_{3} / \mathrm{MgO}-\mathrm{CaO}$ 
In Fig. 2 the effect of $\mathrm{Ni} /$ Dolomite catalyst on the gas compositions in biomass gasification and reforming with fluidized bed.

\section{DISCUSSION}

The effect of Ni/dolomite catalyst: Form the previous study, Srinakruang et al. ${ }^{[12-13]}$ have presented the effectiveness and performance of $\mathrm{Ni} /$ Dolomite catalyst that can eliminate tar formation. According to XRD analysis in Fig. 3, the structure of Ni/Dolomite catalyst was observed as $\mathrm{CaCO}_{3}\left(2 \theta=29.48^{\circ}\right)$. It was claimed that $\mathrm{MgNiO}_{2}, \mathrm{NiO}$ and $\mathrm{MgO}$ were detected at 43.0, 43.2 and $62.8^{\circ}$ in the same result as Srinakruang et al. ${ }^{[12-13]}$. $\mathrm{NiO}$ was reduced with hydrogen at $700^{\circ} \mathrm{C}$ to be reduced nickel $\left(\mathrm{Ni}^{(0)}\right)$ form in reaction (1). When gasification was carried on, tar has been derived to react with reduced nickel to form nickel carbide in reaction (2) and finally reacted with steam to be synthesis gas in reaction (3):

$\mathrm{NiO}+\mathrm{H}_{2} \rightarrow \mathrm{Ni}^{(0)}+\mathrm{H}_{2} \mathrm{O}$

$\mathrm{Ni}^{(0)}+\mathrm{C}_{\mathrm{x}} \mathrm{H}_{\mathrm{y}} \rightarrow \mathrm{NiC}_{\mathrm{x}}+\mathrm{H}_{\mathrm{y}}$

$\mathrm{NiC}_{\mathrm{x}}+\mathrm{H}_{\mathrm{y}} \stackrel{\text { Steam }}{\longrightarrow} \mathrm{Ni}+\mathrm{CO}+\mathrm{H}_{2}$

Table 1 shows the characteristics of three types of $\mathrm{Ni} /$ Dolomite catalyst that are used in this experiment.

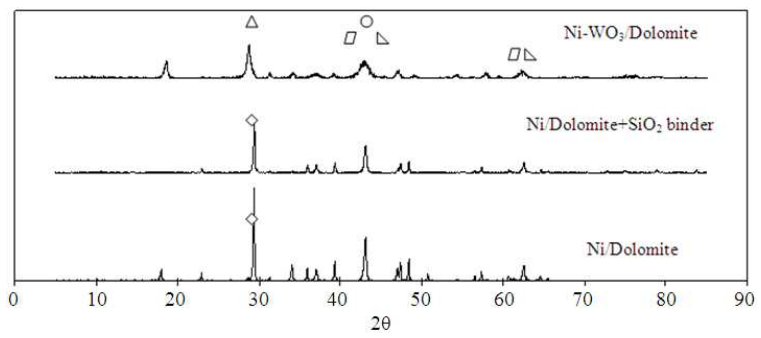

Fig. 3: XRD analysis of three types of Ni/Dolomite catalyst (a) Ni/Dolomite; (b) Ni/Dolomite+ $\mathrm{SiO}_{2}$ binder; (c). $\mathrm{Ni}-\mathrm{WO}_{3} /$ Dolomite $(\diamond) \mathrm{CaCO}_{3}$, ( ) $\mathrm{NiMgO}_{2},(\Delta) \mathrm{NiO},(\mathrm{O}) \mathrm{MgO},(\Delta) \mathrm{CaWO}_{4}$

Table 1: The physical properties of three types of Ni/Dolomite catalysts

\begin{tabular}{|c|c|c|c|c|}
\hline Type & Catalysts & $\mathrm{Ni}$ form ${ }^{\mathrm{a}}$ & $\operatorname{BET}\left(\mathrm{m}^{2} \mathrm{~g}^{-1}\right)^{\mathrm{b}}$ & $\begin{array}{l}\text { Metallic surface } \\
\text { area }\left(\mathrm{m}^{2} \mathrm{~g}^{-1}\right)^{\mathrm{c}}\end{array}$ \\
\hline 1 & $\mathrm{Ni} /$ Dolomite & $\mathrm{NiO}, \mathrm{NiMgO}_{2}$ & 27.0 & 0.5 \\
\hline 2 & $\begin{array}{l}\mathrm{Ni} / \text { Dolomite }+\mathrm{SiO}_{2} \\
\text { binder }\end{array}$ & $\mathrm{NiO}, \mathrm{NiMgO}_{2}$ & 27.0 & 0.4 \\
\hline 3 & $\mathrm{Ni}-\mathrm{WO}_{3} /$ Dolomite & $\mathrm{NiO}, \mathrm{NiMgO}_{2}$ & 30.3 & 1.3 \\
\hline
\end{tabular}

$\mathrm{NiO}$ was the main structure that is the keyword in the tar gasification. Also, BET and metallic surface area are shown in the Table 1. It can be seen that Ni$\mathrm{WO}_{3} /$ Dolomite catalyst has the highest surface area and metallic surface area because of $\mathrm{WO}_{3}$ addition. The arrangement of nickel based on dolomite was regularly dispersed.

$\mathrm{Ni} /$ Dolomite $+\mathrm{SiO}_{2}$ binder was developed because $\mathrm{Ni} /$ Dolomite structure might break during the process of crushing and sieving. $\mathrm{SiO}_{2}$ binder was added to support the stronger structure.

In addition, the newly developed $\mathrm{Ni}-\mathrm{WO}_{3} /$ Dolomite catalyst has been studied to get the highest performance by Sato et $a l .^{[14]}$. It was found that the new catalyst exhibited higher activity at low temperature and better resistance to sulfur and coking. In the new catalyst, an added component that promotes dissociation of the combined sulfur elements accelerates the reactions as shown in Eq. 4 and 5, presumably retaining the lager part of active Ni. Ni-W catalyst is known to be highly active for hydrodesulfurization (HDS). In HDS process, $\mathrm{WS}_{\mathrm{x}}$ on $\mathrm{Ni}$ catalyst promotes conversion of organic sulfur compounds to $\mathrm{H}_{2} \mathrm{~S}$. It is also confirmed that $\mathrm{H}_{2} \mathrm{~S}$ desorbs from sulfide $\mathrm{Ni}$ catalyst in the presence of $\mathrm{H}_{2}$ at high temperature. Therefore, it is possible that $\mathrm{W}$ promotes sulfur dissociation shown in Eq. 4 and 5.

In the Fig. 3, it is shown that XRD analysis of Ni$\mathrm{WO}_{3} /$ Dolomite catalyst which the structure of $\mathrm{Ni} /$ dolomite catalyst was observed as $\mathrm{CaWO}_{4}(2 \theta$ $=18.58$ and $28.74^{\circ}$ ). It has been claimed that $\mathrm{MgNiO}_{2}$, $\mathrm{NiO}$ and $\mathrm{MgO}$ were detected at 43.0, 43.2 and 62.8 ${ }^{\circ}$ :

$\mathrm{NiS}_{\mathrm{x}}+\mathrm{W} \rightarrow \mathrm{Ni}+\mathrm{WS}_{\mathrm{x}}$

$\mathrm{WS}_{\mathrm{x}}+\mathrm{xH}_{2} \rightarrow \mathrm{W}+\mathrm{xH}_{2} \mathrm{~S}$

Also, The SEM photography of three catalysts is presented to see the impregnated characterization of $\mathrm{Ni}$ based on dolomite as shown in Fig. 4. The dispersion of $\mathrm{Ni}$ based on dolomite may be seen after binder addition. $\mathrm{Ni}-\mathrm{WO}_{3} /$ Dolomite catalyst was found that nickel is dispersed and arranged regularly more than $\mathrm{Ni} /$ Dolomite and $\mathrm{Ni} /$ Dolomite $+\mathrm{SiO}_{2}$ binder.

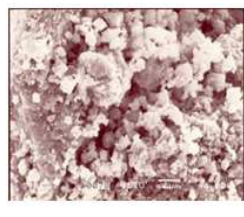

NiDolomite

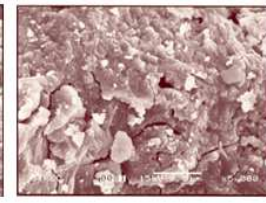

Ni Dolomite $+\mathrm{SiO}_{2}$ binder

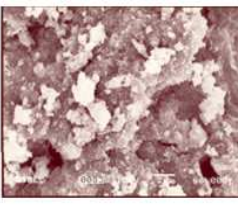

$\mathrm{Ni}-\mathrm{WO}_{3}$ Dolomite
Fig. 4: The dispersion of Ni-supported on dolomite catalyst by SEM photography 


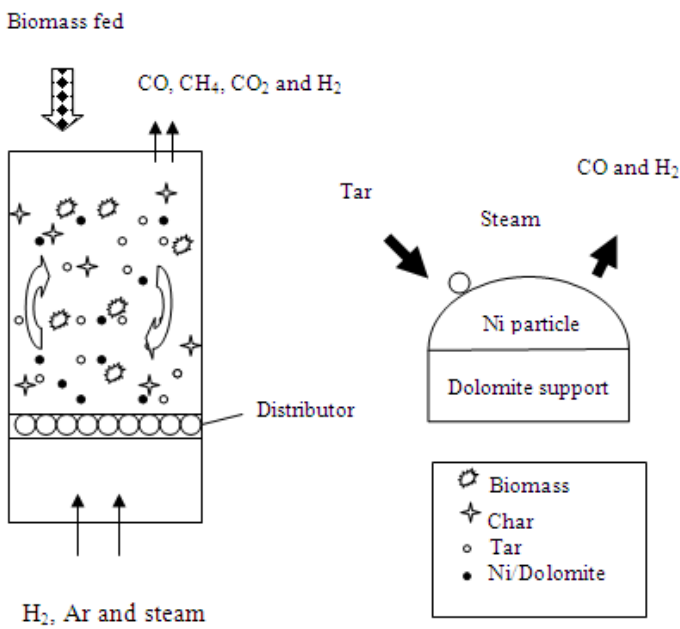

Fig. 5: The mechanism of biomass gasification in fluidized bed with $\mathrm{Ni} /$ Dolomite catalyst

Figure 5 could explain the mechanism that occurs in the fluidized bed after biomass was fed. Actually, the effective of biomass gasification with fluidized bed occurred as well as the suitable conditions are found. When gasification occurred, biomass was gasified with steam to produce gases, tar and char. Tar was eliminated with $\mathrm{Ni} /$ Dolomite catalyst lead to the synthesis gas. Char was reacted with steam to the gaseous products. Moreover, water gas shift and steam reforming which are the reversible reactions were also the important role to form gaseous products:

$$
\begin{aligned}
& \text { Biomass } \rightarrow \mathrm{CO}+\mathrm{CO}_{2}+\mathrm{CH}_{4}+\mathrm{H}_{2} \\
& \mathrm{Tar}+\mathrm{H}_{2} \mathrm{O} \stackrel{\mathrm{Ni}}{\longrightarrow} \mathrm{CO}+\mathrm{H}_{2} \\
& \mathrm{Tar}+\mathrm{H}_{2} \mathrm{O} \stackrel{\mathrm{Ni}}{\longrightarrow} \mathrm{CO}_{2}+\mathrm{H}_{2} \\
& \mathrm{Char}+\mathrm{H}_{2} \mathrm{O} \rightarrow \mathrm{CO}+\mathrm{H}_{2}+\mathrm{CO}_{2} \\
& \mathrm{CO}+\mathrm{H}_{2} \mathrm{O} \leftrightarrow \mathrm{CO}_{2}+\mathrm{H}_{2} \\
& \mathrm{CH}+\mathrm{H}_{2} \mathrm{O} \leftrightarrow \mathrm{CO}+\mathrm{H}_{2} \\
& \mathrm{C}+1 / 2 \mathrm{O}_{2} \rightarrow \mathrm{CO} \\
& \mathrm{C}+\mathrm{O}_{2} \rightarrow \mathrm{CO}_{2}
\end{aligned}
$$

\section{CONCLUSION}

Simultaneous gasification and steam reforming of the biomass on $\mathrm{Ni} /$ dolomite catalyst in fluidized bed reactor were studied in the gaseous production in the one stage reactor. The parameters such as temperature, steam flow rate, biomass feed rate, gas flow rate for fluidization, oxygen flow rate and catalyst types were studied to produce the high gaseous products including tar elimination. The temperature at $780^{\circ} \mathrm{C}$, steam flow rate of $222 \mathrm{mmol} \mathrm{h}^{-1}$, gas flow rate for fluidization $450 \mathrm{~mL} \mathrm{~min}{ }^{-1}$ and oxygen input $50 \mathrm{~mL} \mathrm{~min}{ }^{-1}$ were found to be the suitable conditions. The Ni/Dolomite and the developed $\mathrm{Ni} /$ Dolomite were also studied about their performance. It can be confirm that $\mathrm{Ni} /$ Dolomite and the newly developed $\mathrm{Ni}-\mathrm{WO}_{3} /$ Dolomite show high performance in biomass gasification.

\section{ACKNOWLEDGEMENT}

We are grateful to NEDO Project, Prof. Asami and Prof. Li at the University of Kitakyushu for their help and Dr. Kazuhiro Sato at Takuma Co. Ltd, for $\mathrm{Ni} /$ Dolomite catalysts. Also, we have to thank National Center of Excellence for Petroleum, Petrochemicals and Advanced Materials (NCE-PPAM) and Department of Chemical Technology Chulalongkorn University.

\section{REFERENCES}

1. Chaudhari, S.T., S.K. Bej, N.N. Bakhshi and A.K. Dalai, 2001. Steam gasification of biomassderived char for the production of carbon monoxide-rich synthesis gas. Energ. Fuels, 15: 736-42. DOI: 10.1021/ef000278c

2. Asadullah, M., K. Tomishige and K. Fujimoto, 2001. A novel catalytic process for cellulose gasification to synthesis gas. Catal. Commun., 2: 63-8. DOI: 10.1016/S1566-7367(01)00011-5

3. Asadullah, M., T. Miyazawa, S. Ito, K. Kunimori and K. Tomishige, 2003. Demonstration of real biomass gasification drastically promoted by effective catalyst. Applied Catal. A: General, 246: 103-16. DOI: 10.1016/S0926-860X(03)00047-4

4. Asadullah, M., T. Miyazawa, S. Ito, K. Kunimori and K. Tomishige, 2002. Role of catalyst and its fluidization in the catalytic gasification of biomass to syngasat low temperature. Ind. Eng.Chem. Res., 41: 4567-75. DOI: 10.1021/ie020112u

5. Asadullah, M., T. Miyazawa, S. Ito, K. Kunimori and K. Tomishige, 2003. Catalyst performance of $\mathrm{Rh} / \mathrm{CeO}_{2} / \mathrm{SiO}_{2}$ in the pyrogasification of biomass. Energ. Fuels, 17: 842-49. DOI: 10.1021/ef0202234z

6. Asadullah, M., T. Miyazawa, S. Ito, K. Kunimori and K. Tomishige, 2003. Catalyst development for the gasification of biomass in the dual-bed gasifier. Applied Catal. A: General, 255: 169-80. DOI: 10.1016/S0926-860X(03)00539-8 
7. Asadullah, M., T. Miyazawa, S. Ito, K. Kunimori and K. Tomishige, 2004. Gasification of different biomasses in dual-bed gasifier system: General combined with novel catalysts with high energy efficiency. Appl. Catalal. A., 267: 95-102. DOI: 10.1016/j.apacata.2004.02.028

8. Asadullah, M., T. Miyazawa, S. Ito, K. Kunimori and K. Tomishige, 2005. Resistance to sulfur poisoning of hot as cleaning catalysts for the removal of tar from the pyrolysis of cedar wood. Applied Catal. B: Environ., 60: 299-307. DOI: 10.1016/j.apcatb.2005.04.2003

9. Tomishige, K., M. Asadullah and K. Kunimori, 2004. Syngas production by biomass gasification using $\mathrm{Rh} / \mathrm{CeO}_{2} / \mathrm{SiO}_{2}$ catalysts and fluidized bed reactor. Catal. Today, 89: 389-403. DOI: 10.1016/j.cattod.2004.01.002

10. Rapagna, S., N. Jand and P.U. Foscolo, 1998. Catalytic gasification of biomass to produce hydrogen rich gas. Hydrogen Energ., 23: 551-57. DOI: S0360-3199(97)00108-0
11. Franco, C., F. Pinto, I. Gulyurtlu and I. Cabrita, 2003. The study of reactions influencing the biomass steam gasification process. Fuel, 82: 835-42. DOI: S0016-2361(02)00313-7

12. Srinakruang, J., K. Sato, T. Vitidsant and K. Fujimoto, 2005. A highly efficient catalyst for tar gasification with steam. Catal. Commun., 6: 437-40. DOI: 10.1016/j.catcom.2005.03.014

13. Srinakruang, J., K. Sato, T. Vitidsant and K. Fujimoto, 2006. Highly efficient sulfur and coking resistance catalysts for tar gasification with steam. Fuel, 85: 2419-26. DOI: 10.1016/j.fuel.2006.04.0260.

14. Sato, K. and K. Fujimoto, 2007. Development of new nickel based catalyst for tar reforming with superior resistance to sulfur poisoning and coking in biomass gasification. Catal. Commun., 8: 1697-1701. DOI: $10.1016 /$ j.catcom.2007.01.028 